\title{
The Influence of Documentary Films on 8th Grade Students' Views about Nature of Science*
}

\author{
Munise Seckin Kapucu ${ }^{a}$ \\ Eskisehir Osmangazi University
}

\author{
Gultekin Cakmakci \\ Hacettepe University
}

\author{
Cemil Aydogduc \\ Hacettepe University
}

\begin{abstract}
This quasi-experimental study aims to investigate the documentary films' influence on 8th grade students' nature of science views. The study's participants were 113 th grade students from two different schools taught by two different teachers. The study was completed over a 6-week period, during which topics related to "Cell Division and Heredity" and "Force and Motion" were covered. In the experimental group, six documentary films were integrated into the science curriculum to teach ideas about nature of science. The control group, however, followed the regular science curriculum. The Views of Nature of Science Elementary Level (VNOS-E) questionnaire developed by Lederman and Ko (2004) was used as the data collection tool. In addition, semistructured interviews were conducted with 28 students using the VNOS-E questionnaire at the beginning and end of the study. The results suggest that students in the control group showed no significant improvement in their understanding about nature of science in response to the instruction. However, students in the experimental group showed statistically improvements in their understanding about four of the five nature of science themes in response to the instruction. In addition, a statistically significant difference was found between the views of the experimental group and those of the control group students in the post-test results for four of the five nature of science themes. The results suggest that the use of documentary films in science classrooms has the potential to enhance students' views about nature of science.
\end{abstract}

Keywords: Nature of science $\bullet$ Documentary film $\bullet$ Movies in science education $\bullet$ Science communication

* This study is adapted from the dissertation entitled "The influence of documentary films on 8th grade students' understanding about the concepts of cell and force and on their views about nature of science."

a Corresponding author

Assist. Prof. Munise Seckin Kapucu (PhD), Department of Elementary Education, Division of Science Education, Faculty of Education, Eskisehir Osmangazi University, Eskisehir, Turkey

Research areas: Curriculum development; Teacher professional programs; Teaching about the nature of science

Email: muniseseckinahotmail.com

b Assoc. Prof. Gultekin Cakmakci (PhD), Department of Science Education, Faculty of Education, Hacettepe University, Ankara, Turkey

Email: cakmakciahacettepe.edu.tr

c Assoc. Prof. Cemil Aydogdu (PhD), Department of Science Education, Faculty of Education, Hacettepe University, Ankara, Turkey Turkey Email: caydogduahacettepe.edu.tr 
Cultivating engaged and scientifically literate citizens is defined as one of the main objectives of several science curricula and policy documents; namely, the American Association for the Advancement of Science [AAAS], 1990; the National Research Council [NRC], 1996; the NGSS Lead States, 2013; Nuffield Twenty First Century Science, 2007; and in the Turkish Science and Technology Education Curriculum (Milli Eğitim Bakanllğı [MEB], 2005, 2013). Understanding nature of science is seen as an essential and critical component of scientific literacy in these documents and curricula (Lederman, 2007). The phrase, nature of science, usually is used to refer to "the epistemology and sociology of science, science as a way of knowing, or the values and beliefs inherent to scientific knowledge and its development" (Lederman, Abd-El-Khalick, Bell \& Schwartz, 2002, p. 498). In the literature in most cases the phrase nature of science has been used to refer to nature of scientific knowledge or the phrase nature of science and nature of scientific knowledge have been used interchangeably; nonetheless, they are quite different (Hodson, 2014). That has caused some misunderstanding; therefore, in this paper NOS refers to nature of scientific knowledge (Lederman, Antink, \& Bartos, 2014). Although there is no single and universally accepted definition of NOS (Erduran \& Dagher, 2014) at present significant academic consensus has been achieved on which aspects of NOS are to be taught in school science classes (Lederman et al., 2002; Smith, Lederman, Bell, McComas, \& Clough, 1997; Smith \& Scharman, 1999). These aspects include teaching students that scientific knowledge, its "facts," "theories," and "laws" are both reliable and tentative (NOS-1), empirically based (based on and/or derived from observations of the natural world) (NOS-2), subjective and/or theory-laden (NOS-3), partly the product of human imagination and creativity (NOS-4), subject to a distinction between observations and inferences (NOS-5), influenced by social and cultural factors (NOS6), and that theories and laws are different kinds of knowledge (NOS-7) (Lederman, 1992, 2007). It was suggested that the first five aspects (NOS1-5) would be suitable for middle school students (Akerson, Abd-El-Khalick, \& Lederman, 2000; Akerson \& Donnelly, 2010; Parker, 2010). Since these five aspects are also the main focus of the Turkish science curriculum (MEB, 2005, 2013), this study focuses on them. The results of performing an intensive study on students, teachers, and scientists' views on NOS show that the greater majority of them hold a variety of naïve views toward NOS (Aydeniz, Baksa, \& Skinner, 2011; Cakmakci, 2012; Lederman, 2007; McComas, 1998; Schwartz, Lederman, \& Crawford, 2004). Therefore, strategies that encourage students and teachers to understand NOS have become desirable. Generally speaking, researchers have used either an implicit or explicit approach in their attempts to enhance students' and teachers' views regarding NOS (Akerson \& Donnelly, 2010; Akerson et al., 2000; Khishfe \& Abd-El-Khalick, 2002; Parker, 2010). Recently, reflective elements have also been given prominence within the explicit approach (Lederman, 2007) with several researchers having proposed that using an explicit-reflective approach to develop students' NOS views was more effective than an implicit approach (Cakmakci, 2012; Kaya, 2011; Khishfe \& Abd-El-Khalick, 2002; Küçük, 2006). In this study, an explicit-reflective instruction of NOS was used as a pedagogical framework in the context of documentary films. Using scenes from thought-provoking documentary films can offer a context-oriented learning environment (Clough, 2006; Guerra-Ramos, Ryder, \& Leach, 2010; Lederman et al., 2014) that can be used to explicitly discuss historical processes and practices that have advanced scientific and technological knowledge (Blasco, Moreto, Roncoletta, Levites, \& Janaudis, 2006; Dark, 2005; Efthimiou \& Llewellyn, 2006, 2007; Öztaş, 2008; Piliouras, Siakas, \& Seroglou, 2011; Rose, 2003; Weber \& Silk, 2007). It has been suggested that explicit-reflective NOS instruction would be more effective if more context-specific activities were used during actual instruction (Duschl \& Grandy, 2013; Guerra-Ramos et al., 2010). Many people intentionally or unintentionally use television, Internet, or newspapers more than any other medium as their primary source of information about science and technology. While the value of popular media in science education has been acknowledged, very little empirical research and guidance exists helping teachers to incorporate such mediums into the science curriculum nor in helping teachers to effectively use these mediums in their classroom practice (Cakmakci \& Yalaki, 2012; Kuzma, 2001; Luis Alvarez, Miller, Levy, \& Svejenova, 2004). This quasi-experimental study aims to investigate the documentary films' influence on $8^{\text {th }}$ grade students' NOS views. The current study aims to address the following research questions:

- What are the differences in control group students' views on NOS before and after the instruction? 
- What are the differences in experimental group students' views on NOS before and after the instruction?

- What are the differences between control and experimental group students' views on NOS after the instruction?

\section{Method}

\section{Design of the Study}

A quasi-experimental design with a non-equivalent pre-test-post-test control group was used in this study. In this design, two $8^{\text {th }}$ grade groups were selected as experimental groups, whereas the other two were selected as control groups. The study's dependent variable was students' views about NOS, whereas the independent variable was science lessons.

In the literature, since long-term intervention seems to be more effective in teaching NOS (Akerson \& Donnelly, 2010; Khishfe, 2008; Khishfe \& Abd-ElKhalick, 2002; Küçük, 2006), the present study was conducted over a six-week period. Documentary films on the topics "Cell Division and Heredity" and "Force and Motion" were used. Alternative concepts within these two fields were also considered while designing instruction (Akyürek \& Afacan, 2012; Aydın \& Balım, 2013; Beichner, 1996; Demir \& Sezek, 2009; Eryllmaz, 2002; Kılınç, 2008; Yllmaz, 2007; Yip, 1998). The key assumption behind this study is that explicitly teaching crucial aspects of NOS through documentary films and placing more emphasis on the areas of NOS which students find difficult, can improve students' understanding of NOS.

\section{Sampling}

This study was conducted in two middle schools, located in Eskişehir, Turkey during the fall semester of the 2012-2013 academic year. A total of $1138^{\text {th }}$ grade students (57 from the experimental groups [EG] and 56 from the control groups [CG]) from four classes, all of whom were taking the compulsory science and technology course, participated in the study. There was no significant difference between the two groups' level of achievement in the science and technology course that they had taken the previous year $\left(t_{(109)}=1.932, p>.05\right)$. Accordingly, two of the classes were randomly selected to be the EG. Both groups were instructed for an equal amount of instructional time.

\section{Intervention}

A pilot study was conducted in a middle school in Eskişehir, Turkey during the unit on Cell Division and Heredity of the $8^{\text {th }}$ grade Science and Technology course. In the pilot study, scenes from Charles Darwin and the Tree of Life (Malick, 2009) documentary were used to teach natural selection, adaptation, and the theory of evolution. Based on the pilot study, materials for the main study were modified. Two middle schools from Eskişehir were selected for the main study, the nature of which was introduced to the teachers whose views regarding the instruction process were taken into account during its modification. During the Cell Division and Heredity unit; scenes from Science and Life-Mendel (Erdem \& Özdemir, 2007a), Science and Life-DNA (Erdem \& Özdemir, 2007b), and Charles Darwin and the Tree of Life (Malick, 2009) documentary films were used in the EG while introducing such concepts as heredity, DNA, the genetic code, adaptation, and evolution. For the Force and Motion unit, Archimedes (Erdem and Özdemir, 2007c), the Wright Brothers: How was the Plane Invented? (Erdem and Özdemir, 2007d) and First Flying Tests (Markham, 2001) documentary films were shown to the students in the experimental group during instruction on the buoyancy of gases and liquids. Before starting the documentary, the teacher simply advised students to carefully watch it, giving no further instruction. For short documentaries [around 5 minutes], the teacher allowed the students to watch the whole documentary, before soliciting their comments. For the longer documentaries [around 14 minutes] on the other hand, the teacher would stop the documentary to discuss and clarify those issues that were not understood by students. After watching the documentary, the teacher explicitly discussed the concepts included in the documentary and themes related to NOS. The teacher first asked which concepts had been covered in the documentary and which scientists had been discussed. He/she then asked students for their opinions about the film. Toward the end of the lesson, the teacher distributed discussion questions specifically prepared for each documentary to students, providing them with sufficient time to write their responses. A sheet, summarizing the documentary and the issues discussed in the classroom, were distributed to the students at the end of the lecture in which NOS themes were emphasized.

The same teachers instructed the control and experimental groups. The first author observed both experimental and control groups, monitoring the whole process throughout the study. The Views of the Nature of Science-Elementary Level 
(VNOS-E) questionnaire was applied as a pre- and post-test. In addition, semi-structured interviews were conducted with 28 students by using the questions in the VNOS-E questionnaire. Table 1 summarizes the design of the study.

\begin{tabular}{|c|c|c|c|}
\hline \multicolumn{4}{|c|}{$\begin{array}{l}\text { Table } 1 \\
\text { The Design of the Study }\end{array}$} \\
\hline Group & Pre-test & Application & Post-test \\
\hline 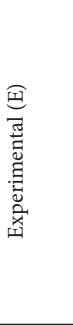 & $\begin{array}{l}\text { VNOS-E ques- } \\
\text { tionnaire was } \\
\text { used in conjunc- } \\
\text { tion with individ- } \\
\text { ual interviews }\end{array}$ & $\begin{array}{l}\text { Instruction as } \\
\text { recommended } \\
\text { by the science } \\
\text { and technology } \\
\text { curriculum } \\
\text { and the use of } \\
\text { documentary } \\
\text { films associ- } \\
\text { ated with the } \\
\text { desired gains } \\
\text { of the science } \\
\text { and technology } \\
\text { curriculum }\end{array}$ & $\begin{array}{l}\text { VNOS-E } \\
\text { question- } \\
\text { naire was } \\
\text { used in } \\
\text { conjunc- } \\
\text { tion with } \\
\text { individual } \\
\text { interviews }\end{array}$ \\
\hline 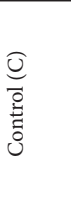 & $\begin{array}{l}\text { VNOS-E ques- } \\
\text { tionnaire was } \\
\text { used in conjunc- } \\
\text { tion with individ- } \\
\text { ual interviews }\end{array}$ & $\begin{array}{l}\text { Instruction as } \\
\text { recommended } \\
\text { by the science } \\
\text { and technology } \\
\text { curriculum }\end{array}$ & $\begin{array}{l}\text { VNOS-E } \\
\text { question- } \\
\text { naire was } \\
\text { used in } \\
\text { conjunc- } \\
\text { tion with } \\
\text { individual } \\
\text { interviews }\end{array}$ \\
\hline
\end{tabular}

\section{Data Collection Instruments}

VNOS-E Questionnaire: VNOS- E developed by Lederman and Ko (2004) was preferred because it was appropriate for elementary level and because it had been adopted into Turkish and used by other researchers (Demir \& Akarsu, 2013; Erenoğlu, 2010). The questionnaire consists of seven openended questions. The VNOS-E and VNOS-D questionnaires have similar questions (Lederman et al., 2002; Metin \& Leblebicioglu, 2012). NOS themes included in the VNOS-E are summarized in Table 2 (Akerson \& Donnelly, 2010; Parker, 2010). Prior to the implementation of the questionnaire, experts compared the Turkish and English versions of the questionnaire to ensure linguistic validity. The VNOS-E Questionnaire has been applied to the students of the EG and CG one week prior to watching the documentaries as a pre-test, and one week after watching them as a post-test.

Semi-structured Interview: Lederman et al. (2002) advised conducting interviews with all or $15-20 \%$ of the students after completing the VNOS questionnaire. The VNOS-E questionnaire was used during the semi-structured interviews conducted both before and after the instruction in order to increase the validity of the study, to reveal deeper meanings that the students have assigned to NOS's features, and to determine their thoughts about the activities.

Face-to-face interviews were conducted with a subsample of the students $(N=28)$ before and after the lesson's instruction. After the implementation of the VNOS-E questionnaire, 2 students with a good, 3 with a moderate, and 2 with a low understanding level of NOS were interviewed in each classroom. The selection process was held in the same way for both the EG and the CG. Interviews were audiorecorded and transcribed for analysis.

\section{Data Analysis}

VNOS-E Questionnaire: A coding scheme developed by Lederman et al. (2002) was used to analyze the data. Students' views about NOS were classified as "Naïve," "Has Merit," and "Informed." Detailed examples of these coding categories are described in the results section. Students' interview responses were analyzed, and each individual participant's responses to the VNOS-E questionnaire were compared to his/her responses in the more open interview context in order to assess the consistency of the participant's responses. In order to ensure the reliability of the analysis, the researchers performed an inter-coder reliability test on the coding. The Cohen Kappa coefficient was checked in order to calculate the reliability of comparative agreement between the two evaluators.

Table 2

NOS Themes Included in the VNOS-E Questionnaire

\begin{tabular}{|c|c|c|c|c|c|c|c|}
\hline & \multicolumn{7}{|c|}{ Questions Included in the VNOS-E Questionnaire } \\
\hline NOS Themes & 1 & 2 & 3 & 4 & 5 & 6 & 7 \\
\hline Scientific knowledge is reliable but is subject to change (NOS-1) & $\checkmark$ & & $\checkmark$ & $\checkmark$ & & $\checkmark$ & \\
\hline Scientific knowledge is empirically-based (NOS-2) & $\checkmark$ & $\checkmark$ & & & & & \\
\hline Scientific knowledge is subjective (NOS-3) & $\checkmark$ & & & & $\checkmark$ & & \\
\hline $\begin{array}{l}\text { Human imagination and creativity play an important role on the produc- } \\
\text { tion of scientific knowledge (NOS-4) }\end{array}$ & $\checkmark$ & & & $\checkmark$ & & & $\checkmark$ \\
\hline Observations and inferences are different (NOS-5) & $\nu$ & & & $\checkmark$ & & $\checkmark$ & \\
\hline
\end{tabular}


Semi-structured Interviews: During the analysis, the records of the interviews conducted with 28 students (14 from each school) were listened to and transcribed. The data obtained from the EG and CG students via the VNOS-E questionnaire were evaluated using a descriptive analysis method. Research data were analyzed in four stages; data coding, identifying themes, defining data, and interpreting the findings. Students were coded in order to maintain the confidentiality. Students' answers given during the interviews were coded as Interview-PR-E-1, Interview-PR-C-1, InterviewPO-E-1, and Interview-PO-C-1, and students' answers to the VNOS-E questionnaire were coded as VNOS-E-PR-E-1, VNOS-E-PR-C-1, VNOS-EPO-E-1, VNOS-E-PO-C-1. The letters PR and PO stands for pre- and post-tests, whereas the letters $\mathrm{E}$ and $\mathrm{C}$ stand for the experimental and control groups, respectively. The remaining number shows the number of students on the data file. The report contains both quotations of students' answers to the VNOS-E questionnaire and interviews.

\section{Findings}

The following sections report EG and CG students' pre- and post-instruction views of NOS. This section consists of a descriptive analysis, statistical results, and interpretations for each sub-problem based on the study's findings. The results were examined within 5 sub-dimensions: (1) scientific knowledge is subject to change, (2) scientific knowledge is empirically-based, (3) scientific knowledge is subjective, (4) human imagination and creativity play an important role in the production of scientific knowledge, and (5) observations and inferences are different in the production of scientific knowledge.
Findings of the VNOS-E Questionnaire: Experimental and Control Groups' Pre-test

The Mann Whitney U-test was applied to the scores of the experimental and control groups' pre-test (VNOS-E questionnaire), whose results show there to be no statistically significant differences between the two groups in four themes of NOS. There was seen, however, to exist a significant difference between the two groups' pre-test scores of NOS theme: "scientific knowledge is empirically-based" ( $U=635.500, p<.05)$. Specifically, the experimental group students' scores were lower than those of the control group students for this specific NOS theme. The U-test results of the groups' VNOS-E questionnaire pre-test scores are given in Table 3.

\begin{tabular}{|c|c|c|c|c|c|c|}
\hline \multicolumn{7}{|c|}{$\begin{array}{l}\text { Table } 3 \\
\text { The Mann Whitney U-test Results of the Groups' VNOS-E Ques- } \\
\text { tionnaire Pre-test Scores }\end{array}$} \\
\hline $\begin{array}{c}\text { NOS } \\
\text { Themes }\end{array}$ & Group & $N$ & $\begin{array}{l}\text { Average } \\
\text { Ranking }\end{array}$ & $\begin{array}{c}\text { Total } \\
\text { Ranking }\end{array}$ & $U$ & $p^{*}$ \\
\hline \multirow[t]{2}{*}{ NOS-1 } & $\begin{array}{l}\text { Experi- } \\
\text { mental }\end{array}$ & 55 & 53.75 & 2956.50 & \multirow[t]{2}{*}{1416.500} & \multirow[t]{2}{*}{.440} \\
\hline & Control & 55 & 57.25 & 3148.50 & & \\
\hline \multirow[t]{2}{*}{ NOS-2 } & $\begin{array}{l}\text { Experi- } \\
\text { mental }\end{array}$ & 40 & 36.39 & 1455.50 & \multirow[t]{2}{*}{635.500} & \multirow[t]{2}{*}{$.024^{\star}$} \\
\hline & Control & 42 & 46.37 & 1947.50 & & \\
\hline \multirow[t]{2}{*}{ NOS-3 } & $\begin{array}{l}\text { Experi- } \\
\text { mental }\end{array}$ & 38 & 37.11 & 1410.00 & \multirow[t]{2}{*}{669.000} & \multirow[t]{2}{*}{.210} \\
\hline & Control & 41 & 42.68 & 1750.00 & & \\
\hline \multirow[t]{2}{*}{ NOS-4 } & $\begin{array}{l}\text { Experi- } \\
\text { mental }\end{array}$ & 55 & 57.53 & 3164.00 & \multirow[t]{2}{*}{1401.000} & \multirow[t]{2}{*}{.388} \\
\hline & Control & 55 & 53.47 & 2941.00 & & \\
\hline \multirow[t]{2}{*}{ NOS-5 } & $\begin{array}{l}\text { Experi- } \\
\text { mental }\end{array}$ & 54 & 54.98 & 2969.00 & \multirow[t]{2}{*}{1378.000} & \multirow[t]{2}{*}{.704} \\
\hline & Control & 53 & 53.00 & 2809.00 & & \\
\hline
\end{tabular}

The results indicate that the experimental and control groups' students share similar conceptions of four of the five NOS themes with only both groups' conception of NOS theme, "Scientific knowledge is empirically-based" differing.

\begin{tabular}{|c|c|c|c|c|c|c|c|c|c|}
\hline \multirow[t]{2}{*}{ NOS } & \multirow[t]{2}{*}{ Control Group } & \multicolumn{2}{|c|}{ Naive } & \multicolumn{2}{|c|}{ Has merit } & \multicolumn{2}{|c|}{ Informed } & \multicolumn{2}{|c|}{ Total } \\
\hline & & $N$ & $\%$ & $N$ & $\%$ & $N$ & $\%$ & $N$ & $\%$ \\
\hline \multirow{2}{*}{ NOS-1 } & Pre-test & 4 & 7.3 & 43 & 78.2 & 8 & 14.5 & 55 & 100 \\
\hline & Post-test & 2 & 3.6 & 51 & 91.1 & 3 & 5.4 & 56 & 100 \\
\hline \multirow{2}{*}{ NOS-2 } & Pre-test & 22 & 52.4 & 17 & 40.5 & 3 & 7.1 & 42 & 100 \\
\hline & Post-test & 23 & 53.5 & 17 & 39.5 & 3 & 7.0 & 43 & 100 \\
\hline \multirow{2}{*}{ NOS-3 } & Pre-test & 21 & 51.2 & 19 & 46.3 & 1 & 2.4 & 41 & 100 \\
\hline & Post-test & 29 & 69.0 & 13 & 31.0 & 0 & 0 & 42 & 100 \\
\hline \multirow{2}{*}{ NOS-4 } & Pre-test & 9 & 16.4 & 36 & 65.5 & 10 & 18.2 & 55 & 100 \\
\hline & Post-test & 7 & 12.5 & 39 & 69.6 & 10 & 17.9 & 56 & 100 \\
\hline \multirow{2}{*}{ NOS-5 } & Pre-test & 25 & 47.2 & 28 & 52.8 & 0 & 0 & 53 & 100 \\
\hline & Post-test & 29 & 51.8 & 27 & 48.2 & 0 & 0 & 56 & 100 \\
\hline
\end{tabular}


The number of students actually included in the analysis may be less for some of the NOS themes because some responses could not be placed in any of the categories for each of the five NOS theme. The categories included in each NOS theme are summarized below, with prevailing views being supported with students' statements from the interview.

\section{Findings about the Study's first Research Question}

Descriptive analyses according to the NOS themes were performed on the control group's pre- and post-test results. The percentiles and frequency distribution of the control group's pre- and posttest scores according to the five NOS themes in question are given in Table 4 .

The Wilcoxon Signed Ranks Test was performed in order to determine whether there existed a significant difference between the control group students' views regarding the five NOS themes before and after the instruction. According to the results of the Wilcoxon Signed Ranks Test, there was no statistically significant difference between the pre- and post-test scores of control group students' views regarding NOS themes (See Table 5).

\begin{tabular}{|c|c|c|c|c|c|}
\hline \multicolumn{6}{|c|}{$\begin{array}{l}\text { Table } 5 \\
\text { Wilcoxon Signed Ranks Test Results of Control Group's Pre and } \\
\text { Post-test Scores about NOS Themes }\end{array}$} \\
\hline NOS & Post-Pre Test & $n$ & $\begin{array}{c}\text { Average } \\
\text { Rank }\end{array}$ & $\begin{array}{l}\text { Total } \\
\text { Rank }\end{array}$ & $z$ \\
\hline \multirow{3}{*}{ NOS-1 } & Negative Rank & 8 & 7.00 & 56.00 & .832 \\
\hline & Positive Rank & 5 & 7.00 & 35.00 & \\
\hline & Same & 42 & & & \\
\hline \multirow{3}{*}{ NOS-2 } & Negative Rank & 8 & 7.50 & 60.00 & .535 \\
\hline & Positive Rank & 6 & 7.50 & 45.00 & \\
\hline & Same & 25 & & & \\
\hline \multirow{3}{*}{ NOS-3 } & Negative Rank & 8 & 6.00 & 48.00 & 1.508 \\
\hline & Positive Rank & 3 & 6.00 & 18.00 & \\
\hline & Same & 23 & & & \\
\hline \multirow{3}{*}{ NOS-4 } & Negative Rank & 7 & 8.50 & 59.50 & .500 \\
\hline & Positive Rank & 9 & 8.50 & 76.50 & \\
\hline & Same & 39 & & & \\
\hline \multirow{3}{*}{ NOS-5 } & Negative Rank & 8 & 8.00 & 64.00 & .258 \\
\hline & Positive Rank & 7 & 8.00 & 56.00 & \\
\hline & Same & 38 & & & \\
\hline
\end{tabular}

${ }^{*} p<.05$.
Findings of the Control Group Regarding the Theme: "Scientific knowledge is reliable but is subject to change"

According to control group students' pre-test results, it has been found that $7 \%$ of the students held views which were naïve, the majority's (78\%) had merit, and the remaining 15\% held informed views on the theme: "scientific knowledge is subject to change." The post-test results for the same group of students, however, show that $4 \%$ of the students held naïve views, the majority (91\%) held views which had merit, and 5\% held informed views (Table 4). For this theme, both students' answers to questions 1, 3, 4, and 6 on the VNOS-E and their answers to the interview questions were considered. The review of the control group's posttest results revealed that those individuals falling into the having merit category stated that scientific knowledge might change; however, they could not or did not explain reasons for this change. The deciding factor for their being placed into the having merit category was the fact that they could not exemplify this change. One student stated, "Science is an evidence-based activity, but it can always change" [VNOS-E-PO-C-8](Q.1). Those students who did provide an explanation for change usually stated that scientific knowledge may change with technological advances and time.

\section{Findings of the Control Group Regarding the NOS theme: "Scientific knowledge is empirically-based (based on and/or derived from observations of the natural world)"}

Based on the control group students' pre-test results, it was seen the majority (52\%) held naïve, $41 \%$ had merit, and $7 \%$ held informed views on the theme: "Scientific knowledge is empirically-based." According to the same groups' post-test results, it was found that $54 \%$ held naïve, $40 \%$ had merit, and $7 \%$ held informed views (Table 4 ). On reviewing the control group's post-test results, one of the students, whose view on this theme was naïve, stated, "Science means reaching an objective judgment by examining the details of a particular topic" [VNOS-E-PO-C-56] (Q.1) whereas another student said, "Science creates a hypothesis and objective judgments are needed in order to validate it. Studies are undertaken to reach these objective judgments" [Interview-PO-C-16] (Q.1). As can be seen from these examples, students consider science to be a compilation of objective judgments instead of inferences. 
Findings of the Control Group Regarding the NOS theme: "Scientific Knowledge is Subjective"

According to the control group students' pre-test results, it was found that the majority $(51 \%)$ of the students held views which were naïve, $46 \%$ had merit, and only $2 \%$ held informed views on the NOS theme "scientific knowledge is subjective." Regarding the post-test results for the same group, the majority (69\%) held views, which were naïve, $31 \%$ had merit, and none of the students in the control group held informed view (Table 4). Students' views on this theme were derived from their answers to question 5 in the VNOS-E and from the interviews. One of the students holding a naïve view stated, "They have various ideas because they don't know why they're dying" [Interview$P O-C-2](Q .5)$, whereas another views supporting it was "Maybe they died immediately, without feeling pain from the disease, we can't know for sure. That means scientists all have different information" [VNOS-E-PO-C-5](Q.5). Students were placed in this category because of their belief that the divergence in scientists' opinions is based on the lack of sufficient data and that if there were enough data, all scientists would be in agreement.

Findings of the Control Group Regarding the NOS theme: "Human Imagination and Creativity play an Important Role in the Production of Scientific Knowledge”

Based on the control group students' pre-test results, it was found that $16 \%$ of the students held views which were naïve, most of them (66\%) held views which had merit, and $18 \%$ held informed views on the theme: "human imagination and creativity play an important role in the production of scientific knowledge." According to the post-test results of the same group, $13 \%$ held views which were naïve, the majority $(70 \%)$ held views, which had merit, and $18 \%$ held informed views (Table 4). Students' views were derived from their answers to questions 4 and 7 on the VNOS-E and from the interviews. A review of the control group's post-test results revealed that individuals whose views have merit stated that human imagination and creativity had an effect on the production of scientific knowledge; they could not explain this, which was the reason for them to be placed in this category. Students expressed that imagination and creativity are used during several stages of the scientific knowledge production process. One student stated, "Science is what people do using their imagination and creativity"[VNOS-E-PO-C-52](Q.1), while another stated, "Science emerged as a result of people's needs. It's like the integration of nature and man. For me, imaginary things are related to imagination. I mean we inspire from nature. But we plan them in our minds first, or we imagine them. Then we do them. I think this is science: The relationship between nature and man." [Interview-PO-C-15](Q.1).

\section{Findings of the Control Group on the NOS Theme: "Observations and Inferences are Different"}

According to the control group's pre-test results, $47 \%$ of the students held naïve views and $33 \%$ had views which had merit on the theme: "observations and inferences are different." None of the participants held an informed view on this theme in the control group. According to the post-test results for the same group, $52 \%$ held naïve views, $48 \%$ held views, which had merit, and none held informed views (Table 4). Students' views of this theme were derived from their answers to questions 4 and 6 on the VNOS-E. A review of the control group's post-test results revealed that individuals' views were placed into the naïve category because

\begin{tabular}{|c|c|c|c|c|c|c|c|c|c|}
\hline \multicolumn{10}{|c|}{$\begin{array}{l}\text { Table } 6 \\
\text { Percentiles and Frequency Distribution of Experimental Group's Pre-and Post-test Scores according to NOS Themes }\end{array}$} \\
\hline \multirow[t]{2}{*}{ NOS } & \multirow[t]{2}{*}{ Experimental Group } & \multicolumn{2}{|c|}{ Naive } & \multicolumn{2}{|c|}{ Has merit } & \multicolumn{2}{|c|}{ Informed } & \multicolumn{2}{|c|}{ Total } \\
\hline & & $N$ & $\%$ & $N$ & $\%$ & $N$ & $\%$ & $N$ & $\%$ \\
\hline \multirow{2}{*}{ NOS-1 } & Pre-test & 7 & 12.7 & 41 & 74.5 & 7 & 17.7 & 55 & 100 \\
\hline & Post-test & 1 & 1.8 & 39 & 68.4 & 17 & 29.8 & 57 & 100 \\
\hline \multirow{2}{*}{ NOS-2 } & Pre-test & 31 & 77.5 & 7 & 17.5 & 2 & 5.0 & 40 & 100 \\
\hline & Post-test & 28 & 56.0 & 16 & 32.0 & 6 & 12.0 & 50 & 100 \\
\hline \multirow{2}{*}{ NOS-3 } & Pre-test & 25 & 65.8 & 12 & 31.6 & 1 & 2.6 & 38 & 100 \\
\hline & Post-test & 17 & 32.1 & 31 & 58.5 & 5 & 9.4 & 53 & 100 \\
\hline \multirow{2}{*}{ NOS-4 } & Pre-test & 2 & 3.6 & 45 & 81.8 & 8 & 14.5 & 55 & 100 \\
\hline & Post-test & 2 & 3.5 & 26 & 45.6 & 29 & 50.9 & 57 & 100 \\
\hline \multirow{2}{*}{ NOS-5 } & Pre-test & 24 & 44.4 & 29 & 53.7 & 1 & 1.9 & 54 & 100 \\
\hline & Post-test & 18 & 31.6 & 37 & 64.9 & 2 & 3.5 & 57 & 100 \\
\hline
\end{tabular}


they expressed no view on observation or inference. One student stated, "I believe that the pictures are real because they benefited from scientific truths while preparing them. In the end, they benefited from science. They performed measurements using scientific tools [Interview-PO-C-16] (Q.6)"

\section{Findings about the Study's Second Research Question}

Descriptive analyses about the five NOS themes in question were performed on the pre- and post-tests results of the experimental group. The percentiles and frequency distribution of the experimental group's pre- and post-test scores according to NOS themes are given in Table 6.

A Wilcoxon Signed Ranks Test was performed to determine whether there existed a significant difference on the experimental group students' views on the NOS themes in question before and after the instruction. According to the results, a statistically significant difference exists for four of the five NOS themes (NOS-1-2-3 and 4) between the experimental group students' pre- and post-test scores. There was found to be no statistically significant difference for a single theme (NOS-5) (See Table 7).

\begin{tabular}{|c|c|c|c|c|c|}
\hline \multicolumn{6}{|c|}{$\begin{array}{l}\text { Table } 7 \\
\text { Wilcoxon Signed Ranks Test Results of the Experimental } \\
\text { Group's Pre-and Post-test Scores Regarding NOS Themes }\end{array}$} \\
\hline NOS & Post-Pre Test & $n$ & $\begin{array}{c}\text { Average } \\
\text { Rank }\end{array}$ & $\begin{array}{l}\text { Total } \\
\text { Rank }\end{array}$ & $z$ \\
\hline \multirow{3}{*}{ NOS-1 } & Negative Rank & 3 & 10.50 & 31.50 & $3.266^{\star}$ \\
\hline & Positive Rank & 18 & 11.08 & 199.50 & \\
\hline & Same & 34 & & & \\
\hline \multirow{3}{*}{ NOS-2 } & Negative Rank & 2 & 6.00 & 12.00 & $2.696^{\star}$ \\
\hline & Positive Rank & 12 & 7.75 & 93.00 & \\
\hline & Same & 26 & & & \\
\hline \multirow{3}{*}{ NOS-3 } & Negative Rank & 3 & 10.50 & 31.50 & $3.396^{\star}$ \\
\hline & Positive Rank & 19 & 11.66 & 221.50 & \\
\hline & Same & 16 & & & \\
\hline \multirow{3}{*}{ NOS-4 } & Negative Rank & 3 & 14.00 & 42.00 & $4.041^{\star}$ \\
\hline & Positive Rank & 24 & 14.00 & 336.00 & \\
\hline & Same & 28 & & & \\
\hline \multirow{3}{*}{ NOS-5 } & Negative Rank & 6 & 10.00 & 60.00 & 1.606 \\
\hline & Positive Rank & 13 & 10.00 & 130.00 & \\
\hline & Same & 35 & & & \\
\hline
\end{tabular}

Findings of the Experimental Group on the NOS Theme: "Scientific knowledge is reliable but is subject to change"

According to the experimental group students' pretest results, $13 \%$ held naïve views, the majority (75\%) held views which had merit, and $18 \%$ held informed views on the NOS theme: "scientific knowledge is subject to change." The post-test results the same group found that $2 \%$ of the students held naive views, the majority (68\%) had merit, and $30 \%$ held informed views (Table 6). For this theme, students' answers to questions $1,3,4$, and 6 of the VNOS-E and their answers to the interview questions were considered. A review of the experimental group's post-test results revealed that individuals' views were placed into the having merit category because they stated that scientific knowledge may change, but could not explain this change. Students who did give an example of how scientific knowledge might change usually cited technological advances and time for a reason of this change. One student stated, "Science makes our lives easier and is constantly changing and evolving" [VNOS-E-PO-E-105](Q.1), and another stated, "Yes, I think so, because people's thoughts today are different than in the 1980's. Some technological devices, such as mobile phones, hadn't been invented yet. Now that they've been invented, they can be improved" [Interview-PO-E-25](Q.3).

\section{Findings of the Experimental Group on the NOS Theme: "Scientific knowledge is empirically- based)"}

Students' views regarding this theme were derived from their answers to question 2 of the VNOS-E and from the interviews. Based on the experimental group students' pre-test results, it was found that most of the students (78\%) held naive views, $18 \%$ had merit, and $5 \%$ held informed views on the NOS theme: "Scientific knowledge is empirically-based (based on and/or derived from observations of the natural world)." According to the post-test results for the same, the majority of students (56\%) held naïve views, $32 \%$ had merit, and $12 \%$ held informed views (Table 6).

\section{Findings of the Experimental Group on the NOS Theme: "Scientific Knowledge is Subjective"}

According to the experimental group students' pretest results, it was found that the majority (66\%) of students held naïve views, $32 \%$ had merit, and only $3 \%$ held informed views on the NOS theme: 
"scientific knowledge is subjective". Regarding the post-test results for the same group, $32 \%$ held naïve views, $59 \%$ had merit, and $9 \%$ held informed views (Table 6). Students' views on this theme were derived from their answers to question 5 on the VNOS-E and from the interviews. The views of students who expressed that scientist may have different views and ideas without giving specific examples of such differing a specific example of such differing views were coded as "having merit."

\section{Findings of the Experimental Group about "Human Imagination and Creativity play an Important Role in the Production of Scientific Knowledge”}

Based on the experimental group students' pre-test results, it was found that $4 \%$ of the students held naïve views, the majority's ( $82 \%$ ) had merit, and $15 \%$ held informed views on the NOS theme: "human imagination and creativity play an important role in the production of scientific knowledge". According to the post-test results for the same group, it has been found that $4 \%$ held naïve views, $46 \%$ had merit, and the majority (51\%) held informed views (Table 6). Students' views were derived from their answers to questions 1,4 , and 7 on the VNOS-E and from the interviews. A review of the experimental group's posttest results revealed that individuals' views were placed into the category "having merit" stated that although human imagination and creativity have an effect on the production of scientific knowledge, they could not explain this. In this category, students stated that imagination and creativity are used during particular times or stages. One of the answers given to this question was, "They attempt to find and combine the fossils. They attempt to make a prediction. They attempt to deduce something. They aren't sure about dinosaurs' exact shape, they make it according to what they see in their imagination. By guessing, they put the things they found together." [Interview-PO-E-11](Q.4).

\section{Findings of the Experimental Group on the NOS Theme "Observations and Inferences are Different"}

According to the experimental group's pre-test results, it was found that $44 \%$ of the students held naive views, the majority's (54\%) had merit, and 2\% held informed views on the NOS theme: "observations and inferences are different in the construction of scientific knowledge." According to the post-test results for the same group of students, it was found that $32 \%$ held naïve views, the majority's (65\%) had merit, and $4 \%$ held informed views (Table 6). Students' views for this theme were derived from their answers to questions 4 and 6 on the VNOS-E and from the interviews. A review of the experimental group's post-test results revealed that students in the experimental group expressed that the results (inferences) obtained by scientist from experiments and observations are not exact information without being able to give specific details. Their views were therefore coded as "having merit" category. An example of this may be seen in the following student's statement, "They know it from underground fossils and bones. Archaeologists examine them, and then interpret them and give them a shape" [Interview-PO-E-27](Q.4)."

\section{Findings about the Study's Third Research Question}

As discussed earlier, descriptive analyses were performed on the results of both the experimental and control groups' pre- and post-test NOS themes. The percentiles and frequency distribution of each NOS theme are given in Table 4 and 6. A Mann Whitney U-Test was performed to determine whether there existed a significant difference between experimental and control group students' views on NOS themes after the instruction. According to the results of the Mann Whitney U-Test, there were statistically significant differences for four of the five NOS themes (NOS-1-3-4 and 5) between the posttest scores of the experimental and control group students. No statistically significant difference was found for one theme (NOS-2) (See Table 8). The results suggest that while the percentage of students' views falling into the "informed" category increased in experimental group, the percentage of students' views falling into the "naïve" and "has merit" categories mostly increased in the control group.

\begin{tabular}{|c|c|c|c|c|c|}
\hline \multicolumn{6}{|c|}{$\begin{array}{l}\text { Table } 8 \\
\text { Mann Whitney U-Test Results of Experimental Control Group's } \\
\text { Post-test Scores about NOS Themes }\end{array}$} \\
\hline NOS & Group & $n$ & $\begin{array}{c}\text { Average } \\
\text { Rank }\end{array}$ & $\begin{array}{l}\text { Total } \\
\text { Rank }\end{array}$ & $U$ \\
\hline \multirow{2}{*}{ NOS-1 } & Experimental & 57 & 64.09 & 3653.00 & $1192.000^{*}$ \\
\hline & Control & 56 & 49.79 & 2788.00 & \\
\hline \multirow{2}{*}{ NOS-2 } & Experimental & 50 & 47.00 & 2350.00 & 1075.000 \\
\hline & Control & 43 & 47.00 & 2021.00 & \\
\hline \multirow{2}{*}{ NOS-3 } & Experimental & 53 & 56.38 & 2988.00 & $669.000^{*}$ \\
\hline & Control & 42 & 37.43 & 1572.00 & \\
\hline \multirow{2}{*}{ NOS-4 } & Experimental & 57 & 67.16 & 3828.00 & $1017.000^{*}$ \\
\hline & Control & 56 & 46.66 & 2613.00 & \\
\hline \multirow{2}{*}{ NOS-5 } & Experimental & 57 & 63.13 & 3598.50 & $1246.500^{*}$ \\
\hline & Control & 56 & 50.76 & 2842.50 & \\
\hline
\end{tabular}

The control group's post-test results show that the percentages of students' views falling into the "naïve" category for the two themes: "Scientific knowledge is reliable, but is subject to change 
(NOS-1)" and "human imagination and creativity play an important role in the production of scientific knowledge (NOS-4)" decreased whereas the percentages of students' views falling into the "naïve" category increased for the following three themes: "scientific knowledge is empirically-based (NOS-2)," "scientific knowledge is subjective (NOS3)," and "observations and inferences are different on the creation of scientific knowledge (NOS-5)" (See Table 4). Regarding the "has merit" category, decreases in the percentage of students whose views fell into the "has merit" were observed for the NOS-2 theme whereas an increase in students' percentages was observed for the following four NOS themes: NOS-1-3-4-5)." On the other hand, there was found to be a slight increase in the percentages of students whose views were coded as "informed" for the NOS theme: "scientific knowledge is empirically-based (NOS-2)" and a decrease in the percentages of students whose views were coded as informed for the NOS-1-3-4). There was no difference observed in NOS-5 theme.

The experimental group's post-test results show that the percentages of students' views coded as "naïve" on the five targeted NOS themes decreased (See Table 6). At the same time, the percentages of students' views coded as "informed" on the five NOS themes increased. Regarding those views which "have merit," percentages decreased for NOS- 1 and 5 themes whereas an increase in students' percentages for NOS-2-3 and 4 .

\section{Discussion}

This study aimed to investigate the documentary films' influence on $8^{\text {th }}$ grade students' NOS views. Regarding students' views about NOS themes, there is no statistically significant difference between the control group students' pre- and post-tests. According to these results, it can be concluded that although science literacy is underlined in the vision statement of Turkey's science and technology curriculum (MEB, 2005), the current instruction of cell and force units as recommended by the curriculum does not have a significant effect on improving students' views on NOS themes. A scientifically literate individual is expected to be able to understand and apply NOS themes appropriately; namely, by understanding basic science concepts, principles, laws, and theories (MEB, 2005, 2013). Regarding the science and technology curriculum from this perspective, NOS concepts are mentioned among curriculum objectives which students are expected to acquire. However, the results of this study show that the curriculum is not effective in presenting NOS themes to students. Findings of several other studies in the literature (Erenoğlu, 2010; Kaya, 2011; Metin \& Leblebicioglu, 2012) also support our findings.

Regarding students' views on the five targeted NOS themes, while there were found to be statistically significant differences between the experimental group students' pre- and post-tests for four of the themes (NOS-1-2-3 and 4), no statistically significant difference was found for one theme (NOS-5).

Regarding the post-test results, while there were statistically significant differences between experimental and control group students' views for four of the five targeted NOS themes (NOS1-3-4 and 5), no statistically significant difference was found for one theme (NOS-2). Drawing on these results, it has been seen that documentaries associated with science topics are effective in improving students' views about most of the NOS themes. The documentaries used within the current study cover the themes: "Cell Division and Heredity" and "Force and Motion" in Turkey's $8^{\text {th }}$ grade science and technology course. Both preparation of similar documentaries for the remaining units and the integration of NOS into these units are recommended. Turkish science and technology curriculum (MEB, 2005) includes objectives related to NOS; however, it was seen that the control group students' views did not experience a significant improvement as a result of the recommended instruction process of the science and technology course, indicating that the current curriculum is not effective in presenting students the five NOS themes in question. Therefore, it seems alternative approaches are needed to teach NOS to students. The results of the study indicate that using documentaries on the curriculum's cell and force units, or at least the specific documentaries used in the study, do not have a significant effect on improving students' views on the following NOS theme: "Scientific knowledge is empirically-based". Experiments are important in obtaining scientific information. In the documentaries that the students watched, although students watched scientists performing experiments, the documentaries were watched in a classroom environment. As such, students did not see the execution of the experiment first-hand. Since experiments are important in obtaining scientific information, NOS themes can be supplemented with experiments and presented to students in the school's laboratory. 
In this study, the VNOS-E questionnaire was used to assess students' views about NOS. In the future, studies examining the effects of other NOS themes on students' views for different grade levels by using different assessment tools can be conducted. In Turkey, within the scope of the FATIH project (fatihprojesi.meb.gov.tr) many tablet computers have been distributed to students and teachers in more than 17 cities and 82 schools. One of the most effective places to use visual media is in teaching
NOS. Studies featuring the use of tablet computers in teaching NOS themes and utilizing visual media (videos, animations, films, and documentaries) can be conducted. At the end of science curriculum, links associated with the visuals of each unit can be listed. Videos, animations, and documentary films can be uploaded to these links. This way, teachers can use visual media more effectively in their lectures. E-books supplemented with visual media can also be prepared for teaching NOS themes.

\section{References}

Akerson, V. L., Abd-El-Khalick, F., \& Lederman, N. G. (2000). Influence of a reflective explicit activity-based approach on elementary teachers' conceptions of nature of science. Journal of Research in Science Teaching, 37(4), 295-317.

Akerson, V. L., \& Donnelly, L. A. (2010). Teaching nature of science to K-2 students: What understandings can they attain? International Journal of Science Education, 32(1), 97-124.

Akyürek, E., \& Afacan, O. (2012). Kavram çarkı diyagramı kullanılarak kavram yanılgılarının belirlenmesi. Uluslararası Eğitim Programları ve Öğretim Çalışmaları Dergisi, 2(3), 47-58.

American Association for the Advancement of Science. (1990). Science for all Americans (Benchmarks for Scientific Literacy). New York, NY: Oxford University Press.

Aydeniz, M., Baksa, K., \& Skinner, J. (2011). Understanding the impact of an apprenticeship-based authentic scientific research program on high school students' understanding of scientific inquiry. Journal of Science Education and Technology, 20(4), 403-421.

Aydın, G., \& Balım, A. G. (2013). Öğrencilerin hücre bölünmesi ve kalıtım konularına ilişkin kavram yanılgıları. Eğitim ve Öğretim Araştırmaları Dergisi, 2(1), 338-348.

Beichner, R. J. (1996). The Impact of video data analysis on kinematics graph interpretation skills. American Journal of Physics, 64, 1272-1278.

Blasco, P. G., Moreto, G., Roncoletta, A. F. T., Levites, M. R., \& Janaudis, M. A. (2006). Using movie clips to foster learners' reflection: Improving education in the affective domain. Family Medicine, 38(2), 94-96.

Cakmakci, G. (2012). Promoting pre-service teachers' ideas about nature of science through educational research apprenticeship. Australian Journal of Teacher Education, 37(2), 114-135.

Cakmakci, G., \& Yalaki, Y. (2012). Promoting student teachers' ideas about nature of science through popular media. Trondheim, Norway: S-TEAM/NTNU. Retrieved from http://bit.ly/1Fpyeyz

Clough, M. P. (2006). Learners' responses to the demands of conceptual change: Considerations for effective nature of science instruction. Science Education, 15, 463-494.

Dark, M. (2005). Using science fiction movies in introductory physics. The Physics Teacher, 43(7), 463-465.
Demir, A., \& Sezek, F. (2009). İlköğretim sekizinci sınıf fen ve teknoloji dersi genetik ünitesindeki kavram yanılgılarının giderilmesinde grafik materyallerin etkisi. Eğitim Fakültesi Dergisi, 22(2), 573-587.

Demir, N., \& Akarsu, B. (2013). Ortaokul öğrencilerinin bilimin doğası hakkındaki algıları. Journal of European Education, 2(2), 31-39.

Duschl, R. A., \& Grandy, R. (2013). Two views about explicitly teaching nature of science. Science \& Education, 22(9), 2289-2315.

Efthimiou, C. J., \& Llewellyn, R. A. (2006). Avatars of Hollywood in physical science. The Physics Teacher, 44(1), 28-33.

Efthimiou, C. J., \& Llewellyn, R. A. (2007). Cinema, fermi problems, and general education. Physics Education, 42(3), 253-261.

Erdem, E. (Producer) \& Özdemir, A. T. (Director). (2007a, December, 12). Mendel and Heredity [Episode 29]. [Video file]. The adventure of science. Podcast retrieved from http://bit.ly/1CaiMIC.

Erdem, E. (Producer) \& Özdemir, A. T. (Director). (2007b, December, 12). DNA [Episode 41]. [Video file]. The adventure of science. Podcast retrieved from http://bit. ly/15y2OvK.

Erdem, E. (Producer) \& Özdemir, A. T. (Director). (2007c, December, 12). Archimedes [Episode 37]. [Video file]. The adventure of science. Podcast retrieved from http://bit. ly/1Ef9DO5.

Erdem, E. (Producer) \& Özdemir, A. T. (Director). (2007d, December, 12). The Wright Brothers and the Invention of Flight [Episode 45]. [Video file]. The adventure of science. Podcast retrieved from http://bit.ly/1CgyemU

Erduran, S. \& Dagher, Z. (2014). Reconceptualizing the nature of science for science education: Scientific knowledge, practices and other family categories. Dordrecht, The Netherlands: Springer.

Erenoğlu, C. (2010). Doğada fen ögretiminin 5. sinıf öğrencilerinin bilimin doğası anlayışlarına etkisi (Master's thesis, Ege University, İzmir, Turkey). Retrieved from https://tez.yok.gov.tr/UlusalTezMerkezi 
Eryılmaz, A. (2002). Effects of conceptual assignments and conceptual change discussions on students' misconceptions and achievement regarding force and motion. Journal of Research in Science Teaching, 39(10), 1001-1015.

Guerra-Ramos, M.T., Ryder, J., \& Leach, J. (2010). Ideas about the nature of science in pedagogically relevant contexts: Insights from a situated perspective of primary teachers' knowledge. Science Education, 94(2), 282-307.

Hodson, D. (2014). Nature of science in the science curriculum: Origin, development, implications and shifting emphases. In M. R. Matthews (ed.), International handbook of research in history, philosophy and science teaching (pp. 911970). Dordrecht, The Netherlands: Springer.

Kaya, G. (2011). Fen kavramlarıla ilişkilendirilmiş doğrudan yansıtıcı yaklaşımın ilköğretim öğrencilerinin bilimin doğası hakkındaki görüşlerine ve akademik başarılarına etkisi (Master's thesis, Hacettepe University, Ankara, Turkey). Retrieved from https://tez.yok.gov.tr/ UlusalTezMerkezi

Khishfe, R. (2008). The development of seventh graders' views of nature of science. Journal of Research in Science Teaching, 45(4), 470-496.

Khishfe, R., \& Abd-El-Khalick, F. (2002). Influence of explicit and reflective versus implicit inquiry-oriented instruction on sixth graders' views of nature of science. Journal of Research in Science Teaching, 39(7), 551-578.

Kılınç, A. (2008). Hücre bölünmelerinin öğretiminde yeni bir yaklaşım: "Bölünen parmaklar". Dicle Üniversitesi Ziya Gökalp Eğitim Fakültesi Dergisi, 10, 82-99.

Küçük, M. (2006). Bilimin doğasını ilköğretim 7. sınıföğrencilerine öğretmeye yönelik bir çalışma (Doctoral dissertation, Karadeniz Technical University, Trabzon, Turkey). Retrieved from https://tez.yok.gov.tr/UlusalTezMerkezi

Kuzma L. M. (2001). And, action! Using film to learn about foreign policy. International Studies Perspectives, 2(1), 33-50.

Lederman, J. S., \& Ko, E. K. (2004). Views of nature of science, form E. Unpublished manuscript, Illinois Institute of Technology, Chicago, USA.

Lederman, N. G. (1992). Students' and teachers' conceptions of the nature of science: A review of the research. Journal of Research in Science Teaching, 29(4), 331-359.

Lederman, N. G. (2007). Nature of science: Past, present, and future. In Abell, S. K., \& Lederman, N. G. (Eds.), Handbook of research on science education (pp. 831-879). London: Lawrence Erlbaum Associates.

Lederman, N. G., Abd-El-Khalick, F., Bell, R. L., \& Schwartz, R. (2002). Views of nature of science questionnaire: Toward valid and meaningful assessment of learners' conceptions of nature of science. Journal of Research in Science Teaching, 39(6), 497-521.

Lederman, N.G., Antink, A. \& Bartos, S. (2014). Nature of science, scientific inquiry, and socio-scientific issues arising from genetics: A pathway to developing a scientifically literate citizenry. Science \& Education, 23, 285-302.

Luis Alvarez, J., Miller, P., Levy, J., \& Svejenova, S. (2004). Journeys to the self: Using movie directors in the classroom. Journal of Management Education, 28(3), 335-355.

Malick, T. (Director). (2009). Charles Darwin: The Tree of Life (On the origin of species). [Video file]. UK: BBC.

Markham, M. (2001). Fly past [Video file]. Podcast retrieved from http://bit.ly/1BEB99v.
McComas, W. F. (1998). The principal elements of the nature of science: Dispelling the myths. In W. F. McComas (Ed.), The nature of science in science education: Rationales and strategies (pp. 53-70). Dordrecht: Kluwer.

Metin, D., \& Leblebicioglu, G. (2012). Effect of a science camp on the children's views of tentative nature of science. Journal of Studies in Education, 2(1), 164-183.

Milli Eğitim Bakanlığı. (2005). İlköğretim 6., 7. ve 8. sinıf fen ve teknoloji dersi ögretim programları. Ankara: Milli Eğitim Bakanlığı Talim ve Terbiye Kurulu Başkanlığı.

Milli Eğitim Bakanlığı. (2013). Fen bilimleri dersi öğretim programı. Ankara: Milli Eğitim Bakanlığı Talim ve Terbiye Kurulu Başkanlığı.

National Research Council. (1996). National science education standards. Washington, DC: National Academy Press.

NGSS Lead States. (2013). Next generation science standards: For states, by states. Washington, DC: National Academies Press.

Nuffield Twenty First Century Science. (2007). Twenty first century science resources. Retrieved 11 January 2015 from http://www.21stcenturyscience.org

Öztaş, S. (2008). Tarih öğretimi ve filmler. Kastamonu Ĕgitim Dergisi, 16(2), 543-556.

Parker, E. A. (2010). The relationship between nature of science understandings and science self-efficacy beliefs of sixth grade students. Middle-Secondary Education and Instructional Technology Dissertations. Georgia State University, Atlanta.

Piliouras, P., Siakas, S., \& Seroglou, F. (2011). Pupils produce their own narratives inspired by the history of science: Animation movies concerning the geocentric heliocentric debate. Science \& Education, 20(7-8), 761-795.

Rose, C. (2003). How to teach biology using the movie science of cloning people, resurrecting the dead, and combining flies and humans. Public Understanding of Science, 12(3), 289-296.

Schwartz, R. S., Lederman, N. G., \& Crawford, B. (2004). Developing views of nature of science in an authentic context: An explicit approach to bridging the gap between nature of science and scientific inquiry. Science Education, 88(4), 610-645.

Smith, M. U., Lederman, N. G., Bell, R. L., McComas, W. F., \& Clough, M. P. (1997). How great is the disagreement about the nature of science? A response to alters. Journal of Research in Science Teaching, 34(10), 1101-1103.

Smith, U. M., \& Scharmann, L. C. (1999). Defining versus describing the nature of science: A pragmatic analysis for classroom teachers and science educators. Science Education, 83(4), 493-509.

Weber, C. M., \& Silk, H. (2007). Movies and medicine: An elective using film to reflect on the patient, family, and illness. Family Medicine, 39(5), 317-319.

Yllmaz, S. (2007). Öğrencilerin fizikteki kavram yanılgilarina yardimci olacak temel benzetmelerin bulunmast (Doctoral dissertation, Middle East Technical University, Ankara, Turkey). Retrieved from https://tez.yok.gov.tr/ UlusalTezMerkezi

Yip, D. Y. (1998). Identification of misconceptions in naive biology teachers and remedial strategies for improving biology learning. International Journal of Science Education, 20(4), 461-477. 